\title{
ORIGINAL RESEARCH \\ Dialogues of Joy: Shared Moments of Joy Between Teachers and Children in Early Childhood Education Settings
}

\author{
Satu Karjalainen ${ }^{1}$ (D) $\cdot$ Eija Hanhimäki ${ }^{2}$ - Anna-Maija Puroila ${ }^{1}$ (D)
}

Published online: 20 July 2019

(c) The Author(s) 2019

\begin{abstract}
The study focuses on teachers' and children's shared moments of joy in early childhood education settings and contributes new knowledge in educational research by exploring joy as a relational rather than an individual phenomenon. The theoretical and methodological framework draws on a narrative approach and Martin Buber's dialogical philosophy. Data were gathered through video observations and diary notes in open ECE groups in Finland, with children from 2 to 6 years. The scenes of everyday life in ECE appeared to radiate an overall positive atmosphere. However, the relationship between shared joy and dialogue was multifaceted. On one hand, joyful moments between teachers and children provided opportunities for dialogical encounters. On the other hand, there were variations in how children could participate in joyful moments. The study challenges educators to reflect on the significance of joy in pedagogical practices. The study revealed that dialogical, joyful encounters do not occur due to purposeful planning. Instead, they require that teachers value the daily, bursting-forth moments as important spaces to create reciprocal, respectful relationships with children.
\end{abstract}

Keywords Buber $\cdot$ Dialogue $\cdot$ Early childhood education $\cdot$ Narrative inquiry $\cdot$ Shared joy

\section{Résumé}

L'étude se concentre sur des moments de joie partagée entre enseignants et enfants dans des contextes d'éducation de la petite enfance (ÉPE). Elle contribue à de nou-

Satu Karjalainen

satu.karjalainen@oulu.fi

Eija Hanhimäki

eija.hanhimaki@gmail.com

Anna-Maija Puroila

anna-maija.puroila@oulu.fi

1 Faculty of Education, University of Oulu, Erkki-Koiso Kanttilan katu 1, 90014 Oulu, Finland

2 Faculty of Education and Psychology, University of Jyväskylä, Alvar Aallon katu 9,

40014 Jyväskylä, Finland 
velles connaissances dans la recherche en éducation en explorant la joie comme phénomène relationnel plutôt qu'individuel. Le cadre théorique et méthodologique s'appuie sur une approche narrative et sur la philosophie dialogique de Martin Buber. Les données ont été collectées à partir d'observations sur vidéo et de notes de journal dans des groupes ouverts d'ÉPE en Finlande, avec des enfants de 2 à 6 ans. Les scènes de la vie quotidienne en ÉPE semblent irradier une atmosphère globalement positive. Toutefois, la relation entre joie partagée et dialogue comporte de multiples facettes. D'un côté, les moments joyeux entre enseignants et enfants donnent des occasions de rencontres dialogiques. D'un autre côté, il y a de la variation dans la façon dont les enfants peuvent participer aux moments joyeux. L'étude met les éducateurs au défi de réfléchir à la signification de la joie dans les pratiques pédagogiques. L'étude révèle que les rencontres dialogiques, joyeuses, ne se produisent pas en raison d'une planification délibérée. Au contraire, elles requièrent que les enseignants valorisent les moments du quotidien surgissant spontanément en tant qu'espaces importants pour créer des relations réciproques respectueuses avec les enfants.

\section{Resumen}

El presente estudio se enfoca en momentos de alegría compartida entre educadores y niños en el contexto de la educación infantil temprana o preescolar y aporta nuevo conocimiento a la investigación educativa mediante la exploración de la alegría como fenómeno de relación y no sólo individual. El marco teórico y metodológico utiliza el método narrativo y la filosofía dialógica de Martin Buber. Se recolectaron datos mediante observaciones de video y notas en diarios en grupos abiertos de preescolar en Finlandia con niños de edades entre los 2 y 6 años. Las escenas de la vida diaria en la educación preescolar parecieron irradiar una atmósfera positiva. Sin embargo, la relación entre alegría compartida y diálogo mostró varias facetas. Por un lado, los momentos de alegría entre educadores y niños brindaron oportunidades de encuentros de diálogo. Por otro lado, se observaron variaciones en la forma en que los niños podían participar en momentos de alegría. El estudio reta a los educadores a reflejar sobre la importancia de la alegría en prácticas pedagógicas. El estudio reveló que encuentros alegres y de diálogo no ocurren como consecuencia de una planeación concienzuda sino que requieren que los educadores valoren momentos diarios de dicha como espacios importantes para crear relaciones de mutuo respeto con los niños.

\section{Introduction}

This study focuses on teachers' and children's shared moments of joy in the Finnish context of institutional early childhood education (ECE). Especially in Western cultures, joy, happiness and carefreeness are regarded as essential features of a desirable childhood (Vehkalahti 2012). In the education sciences, an increasing body of the literature discusses positive emotions, including joy, as prerequisites for children's learning and comprehensive well-being (Hinton et al. 2008). Several ECE studies have addressed topics related to joy, such as playfulness (Singer 2013) and humour (Tallant 2015). However, few education studies have explicitly focused on 
shared joy. As Cekaite and Andrén (2019, p. 2) noted, 'little research, and especially research that attends in detail to the social characteristics of laughter and emotion sharing, is available on children's laughter in contexts other than homes, although an increasing group of children worldwide spend a large part of their everyday life in early childhood education institutions'. Moreover, many previous studies on joy and other positive emotions drew on the theory of individual psychology and focused on individually experienced joy and emotion regulation (Huhtamäki et al. 2017; Kurki 2017). The research question guiding this study is: How do shared moments of joy between teachers and children appear in everyday life in ECE settings?

This study contributes to the education research literature by approaching joy as a relational rather than an individual phenomenon. Buber's (1923/1987, 1947/2002) dialogic philosophy and narrative approach (Clandinin et al. 2017) provided the theoretical and methodological basis for investigating how joy emerged in relationships between teachers and children. The study aim was to explore moments of joy shared by teachers and children in ECE settings. The study is a continuation of the previous research addressing shared moments of joy among children (Karjalainen and Puroila 2017). The results from the previous research showed that cultural codes in ECE settings shaped expressions of joy in children's peer activities and that children rejoiced differently and in livelier ways when no teachers were present. However, daily life in ECE settings also contains moments in which teachers encouraged children's delight and engaged in joyful moments with them. In this study, we turned our focus from joy shared among children to shared moments of joy among teachers and children.

\section{Joy in Education}

This study combines two principles emphasised in education-the emotion of joy and reciprocal relationships. It utilises a sociological approach highlighting emotions as part of human behaviour, interactions and social order (Turner and Stets 2014). Although emotions reflect an individual's internal states, we focused on the emotion of joy from cultural and relational perspectives. We considered the emotional communication among the participants to be performative acts done in relationships with others (see Kuby 2014). Instead of concentrating on the individual psychological feeling of joy, we looked at shared emotions that occur between human beings and are shaped by everyday life in ECE. According to Segal (2018), moments of joy are unexpected and bring people together, raising them above everyday concerns. Our aim is not to evaluate the genuineness or pureness of joy but to explore what is culturally worthy of rejoicing and 'how' and 'where' joy emerged among ECE participants.

The Finnish National Core Curriculum for Early Childhood Education and Care (2016) mentions joy several times, especially in connection to learning, play and children's success. The curriculum highlights that young children's learning should have room for joy. According to the curriculum, positive emotional experiences promote learning, and learning and success, in turn, evoke joy. The curriculum stresses that children and staff should have possibilities to rejoice over play and other joint activities. 


\section{Martin Buber's Dialogic Philosophy}

Dialogue in relationships among teachers and children has been highlighted in education studies (de Vocht 2015). Among the various formulations of dialogical encounters, we were inspired by Buber's (1923/1987, 1947/2002) dialogic philosophy. Buber used the word pairs 'I-Thou' and 'I-It' to describe humans' dual relationships with the world. The 'I-It' relationship refers to one's natural, everyday attitude in which one categorises human beings based on advance knowledge and previous experiences (Buber 1923/1987, 1947/2002). According to Buber, there is no meeting in I-It relationships as they are experienced in human beings, not between human beings. In contrast, the premises of genuine, equal, dialogic 'I-Thou' meetings stretch the individually experienced world. 'I-Thou' meetings occur within one's whole presence and enable stepping in-between and experiencing the other side. The prerequisite of a dialogical meeting is acknowledgement of another human being's otherness and uniqueness. Dialogue is possible only when all means are gone, and it is a direct relationship without objectives or foreknowledge (Buber 1923/1987, 1947/2002).

Buber (1947/2002) emphasised the value of dialogical relationships in education. Still, to maintain its educational nature and to avoid becoming friendship, Buber (1947/2002) considered teachers to be pedagogical filters of the world which makes educational relationships asymmetrical. The asymmetry causes tensions to educational relationships as they should constitute I-Thou relationships based on equity, trust, openness and respect (Bartholo et al. 2010; Buber 1923/1987, 1947/2002). Buber's (1923/1987) formulations about emotions are complex: he claimed that encounters can include but do not produce feelings. Gordon (2001) examined the dialogical perspectives in Buber's Hasidic writings linking joy to human activities rather than psychological feelings. According to Gordon (2001), Buber considered joy to be a blessed moment, appearing both in personal and communal spheres. Buber's (1923/1987, 1947/2002) dialogic perspectives provided us with a fruitful, holistic perspective for exploring the shared aspects of joyful moments. We attempted not to locate authentic, reciprocal dialogue in shared moments of joy as 'here it stands' but instead to consider dialogic philosophy to be a communicative stance the participants utilised in their everyday life in ECE.

\section{Narrative Approach to Shared Moments of Joy}

The theoretical and methodological underpinnings of this study were inspired by narrative research, an inclusive concept encompassing a range of methodologies (Clandinin et al. 2017). Narrative research studies have used the concepts of narrative and story differently. Some have considered the terms to be synonyms, while others have drawn a distinction between them (see Hyvärinen 2008). We employed the concept of an everyday narrative, understanding it to be a broader concept than a story. Whereas a story refers to the content of a narration, the concept of an everyday narrative includes the content and the context of a story and the process through 
which a story is produced. We considered shared joyful moments in ECE settings to be relationally lived and co-narrated everyday narratives connected to broader cultural, social, familial and institutional narratives (Caine et al. 2013; Tuval-Mashiach 2014). Everyday narratives do not emerge from nowhere; instead, teachers and children actively narrate joy in multiple ways and in relationship with each other.

Our study rested on the premise that both children and adults live surrounded by diverse narratives. Human beings' lives and narratives are intertwined (SpectorMersel 2010). From birth, children narrate and become narrated by others within the broader culture (Puroila 2013; Bruner 1986). When studying shared moments of joy as a relational phenomenon in ECE, we distinguished three contextual spheres in which everyday narratives are situated: the immediate inter-subjective context; the collective social field of institutional ECE; and the broader cultural meta-narratives constituting the shared meaning system within which single narratives are understandable (Tuval-Mashiach 2014).

Previous studies explored narratives at multiple levels. Recent research has challenged the traditional conceptualisation of a narrative as a coherent, linear whole with a specific structure (Hyvärinen et al. 2010). In this study, we joined researchers calling for attending to the interactional processes and the contexts of stories (e.g. Lannaman and McNamee 2011). Our study focused on teachers' and young children's shared moments of joy, so we dealt with diverse ways of narrating. Recent narrative childhood studies have approached narrating as a multimodal process (Juutinen and Viljamaa 2016; Kinnunen 2015). Young children have still-developing verbal capacities (de Vocht 2015), so reducing narratives to verbal interactions neglects the multifaceted nature of children's and adults' emotional narrating. We considered narrating to extend beyond verbal speech to gestures, body movements, sounds and facial expressions.

\section{Methodology}

\section{Research Context, Participants and Researchers}

This research was conducted with five open ECE groups of eight to twenty 2- to 6-year-old children, two teachers and an assistant in one city of northern Finland. Finnish open ECE is an alternative service to children who do not join the full-day ECE. Open ECE groups function two or three times per week, $3 \mathrm{~h}$ per day. Before gathering the research material, we obtained consent from the children, their parents, the teachers and the municipal education administration. We also informed the participants about the study aims and schedule. The child groups met for 3-h sessions for two or three times per week. The groups were quite permanent, but as typical in open ECE, the children in the groups changed throughout the semester as they moved to other groups in the same setting or to full-day programmes, and some new children joined during the research process. The teachers and assistants also changed during the data collection period, yielding a total of four teachers in this research material. 
The first two authors gathered and analysed the research material, while the third author joined the writing phase. The first and third authors had ECE backgrounds as preschool teachers and researchers. The second author had a research background in religious education and education sciences. Combining this expertise enabled deepening understanding of the study topic from multiple perspectives.

\section{Fieldwork and Research Material}

In recent years, the use of videos in education research has increased. In qualitative studies, video recordings have created rich stories about the research phenomena (Goldman et al. 2007). In ECE research, for example, videos have been used in studies on interactions (see de Vocht 2015; Emilson and Johansson 2009). The research material in this study consisted of videos and notes gathered on single days between 2013 and 2016 and in two 1-week periods in autumn 2015 and spring 2016. Together, all the videos totalled $65 \mathrm{~h}$. They were recorded during the activity time from the morning to the afternoon. The use of four cameras and eight microphones enabled capturing daily events from multiple angles.

Ethical considerations were an essential, continuous component of the research from the field work to the writing process. The participants opened their everyday lives to examination, requiring that we treat their lives and narratives with respectful, ethical sensitivity. Everything we saw, heard, felt and interpreted during the data collection posed ethical issues (see Pink 2009; Viljamaa 2012). In every phase of this research, we attempted to encounter and understand the 'Other', leaning on Buberian philosophy. During the analysis and reporting, we used pseudonyms to refer to the teachers and children. The research materials were stored securely and used only by the research group.

\section{Recognising Moments of Shared Joy as a Methodological Challenge}

How could we recognise shared joy in our research material? It was almost impossible to identify clear beginning and ending points for moments of joy. The teachers, in particular, had a nearly constantly positive habitus and a smiling, joyful essence. When busy with activities other than interacting with children, the teachers tended to have serious or neutral looks, but almost every time they glanced at children, they smiled warmly. Positive emotions (e.g. elation, happiness, gladness and joy) typically are treated as a unitary cluster, and distinguishing them from each other is challenging (Fredrickson 2003; De Rivera et al. 1989). We, therefore, focused on moments when joy was strongly expressed. Children and teachers conveyed joy in many ways: smiling mouths, eyes and faces, laughing glances, laughing together and directly mentioning joy in speech: 'This is fun!' We recognised joy in these expressions and the participants' verbal and bodily dialogue. We also relied on our own cultural and experiential knowledge to identify joyful moments (Karjalainen and Puroila 2017). 


\section{Analysis and Interpretation}

Analysing the research material was a multifaceted process that did not follow a linear path (see Lieblich 2014). We conducted the analysis not as a structured process but through living and communicating with the research material, the research literature and our research team (see Viljamaa 2012). The analysis process had three stages. The first phase of analysis and interpretation occurred during the field work. Interpretation was tightly connected to the situations in which the research material was generated. During the fieldwork, we also began data-driven, inductive analysis to gain an overall picture of the research material. After several comprehensive 'readings' of the recorded material, we found that shared joy seemed to be fleeting and fluctuating by nature and hard to get hold of.

During the second phase, we identified 113 moments of shared joy, lasting from few seconds to a half an hour. When transcribing these joyful moments into written narratives, we felt that this form did not do justice to their sparkling nature (Karjalainen and Puroila 2017; Viljamaa 2012). However, the shared moments of joy gradually began to open up in more detail, and we were able to recognise nuances in the moments. We conducted thematic narrative analysis (Riessman 2008) to gain insights into the contents of the narratives. In this phase, we also consciously interpreted the everyday narratives in the light of Buber's dialogical philosophy. Although we found a variety of themes related to shared moments of joy, the entangled and bouncing nature of joy seemed to get blurred when making themes in the narratives. These moments could not be reduced into exclusive categories as that conflicted with the procedural nature of joy. This phase left us with the feeling Lieblich $(2014$, p. 115) described as losing 'the complete context of what the data expresses'. We, therefore, returned to a more comprehensive approach.

During the third phase, we again watched the videos and pursued dialogue with them. The constant moving between the holistic and the more detailed approach helped us constitute a retold narrative, a big picture of the shared joy in ECE (e.g. Niemi 2013). In the following, we first retell a narrative of joy that penetrated the teachers' and children's daily lives in ECE settings. Next, we take a closer look at two different shared moments of joy. Zooming into these everyday narratives gives a ringside seat at multifaceted, situationally and relationally constructed moments of shared joy.

\section{Findings}

\section{The Big Picture of Shared Moments of Joy: Joy Penetrates the Everyday Life of Early Childhood Education}

The scene of everyday life in ECE appeared to radiate an overall positive atmosphere. Sometimes rejoicing was expressed in quite restrained ways; at times, it was more sparkling, and occasionally, it was even off the hook. Shared joy was present in both teacher-guided activities and informal, spontaneous situations. The following 
retold narrative illustrates the nature of the shared moments of joy between the children and teachers.

The first moments of shared joy between the children and teachers occur when the door of the ECE centre opens. 'I'm so happy to see you again, Maija!' Cheerful greetings are spiced up by a child running into the teacher's lap, hugging the teacher, who tickles the child. The day continues with morning circle time when the whole group gathers together, and various teacher-guided activities take place. In these moments, shared joy reveals itself most clearly. When leading the activities, the teachers make whimsical and exaggerated gestures, which get the children merrily engaged.

In addition to cheering with the whole group, the circle-time activities include moments of individual attention, and every child gets time in the limelight. Joy is conveyed when children know the correct answers to the teachers' questions and succeed in tasks. Additionally, when children share their own experiences, ideas and stories about their families, the teachers provide joyful feedback.

Free playtime is filled with moments of rejoicing together. The children's ideas, know-how and accomplishment of tasks evoke joy. The more effort and struggle success demands, the more cheerful the participants' reactions are. Surprising incidents create joy, such as an object dropping on the floor, forgetting the words of a song and a toy car tumbling and falling upside down. Familiar but exciting things, such as the climax of a well-known song, also make both the children and teachers laugh, sometimes even yell from joy. Nonsense spurs laughter.

In the shared moments of joy, the conventional becomes unconventional; ordinary things are turned upside down: a dustpan is worn as a hat, and the teachers ask the children nonsense and obvious questions, such as if Maija's name is Birgitta. The teachers highlight their own mishaps and clumsiness. The children and teachers laugh together when a teacher gets stuck in a chair or accidentally spills water all over her trousers. The object of the laughter is the teachers. The children's blunders are rarely funny.

Rejoicing between the teachers and children is bodily expressed and acted in different ways of touching: the child climbs onto the teacher's lap or shoulders, and the teacher tickles the child. Although the teachers indulge in rejoicing, they tend to also set boundaries and rules for it. When cheerful activities seem to be physically risky, or nonsense lasts too long, the teachers guide the children to more appropriate activities.

The day in ECE ends with rejoicing over meeting loved ones. In the afternoon, when the doorbell rings, the children get 'bodily alert', and someone announces: 'Sanni, it is your mother!' Sanni, with joyous gestures, runs towards her mother and jumps into an embrace with her. Both the teacher and the mother laugh. The teachers verbally celebrate these moments: 'Oh, you are so happy to see your mommy again. You missed her a lot'.

In this retold narrative, the overall atmosphere in the ECE centre studied was positive. This notion was linked to the concept of a positive emotional climate produced within a certain group through a socially shared, emotionally shaped process (see 
Bellocchi et al. 2014). The narrative of the big picture indicated that the meetings in the morning sparked joy among the children and teachers. Meetings themselves can be seen as both sources and outcomes of joy. When differentiating among positive emotions, de Rivera et al. (1989) noted that joy, in particular, arises in meetings. During these morning and afternoon moments, the participants demonstrated a mutual understanding that they were worth rejoicing. These happy reunions, occurring day after day, mediated the sense of being longed for, which indicated a respect; a basic element in I-Thou encounters (Buber 1923/1987, 1947/2002). The participants rejoiced the presence of each other with their minds and bodies. According to Buber (1947/2002), the dialogical stance is holistic, and the gentle, joyful touching mediated a caring attitude between the teachers and children.

During the joyful shared moments, the participants stepped out of their conventional roles (see Turner 2012). These kinds of moments seemed to come in short bursts, when both achieving the education objectives and being the education object were put aside temporarily. The participants stepped out of their conventional, expected roles and reached for the 'Other', and 'I-Thou' relationship existed for a moment. There was continuous alternation between 'I-It' and 'I-Thou' relationships (Buber 1923/1987): for instance, when the teacher guided the child's cheerful activity towards a prioritised direction, the teacher defined the situation (and the child), the 'Thou' became 'It', and the dialogue was passing.

According to de Vocht (2015), a dialogic stance in education relationships increases children's agency. In the shared joy in the retold narrative, the children characteristically were active participants. They primarily produced the content of the joyful play and conversations, and the teachers acknowledged their perspectives (see Emilson and Johansson 2009). Supporting the children's agency strengthened their feeling of being appreciated. The ECE curriculum also emphasises rejoicing over children's know-how and success (Finnish National Core Curriculum for Early Childhood Education and Care 2016).

Based on the retold narrative, shared joy emerged from unexpected events such as blunders. It burst into everyday life activities, generally could not be prepared for and rapidly passed. In these moments, the participants shared mutual knowledge and cheerfulness about blunders. They utilised their cultural knowledge to understand the moments (see Karjalainen and Puroila 2017). Although culturally shaped, these moments could not be scripted beforehand. The plot of the joyful moment was open and required a dialogical stance to construct it in relationship with others. Also dialogue can be considered as an unpredictable, temporary momentary issue. Dialogue could not be completely controlled and defined; in Buber's (1923/1987, p. 32) words, 'the world which appears to you in this way is unreliable for it takes on a continually new appearance'.

\section{Zooming into Different Shared Moments of Joy}

The previous section tells of an overall, positive, joyful narrative of child-teacher relationships. Shared moments of joy, however, should not be oversimplified. This larger narrative cuts the wings of multifaceted joy and cleans up its diverse, 
situational, sometimes even rough character. More closely scrutinising the shared moments of joy, the following two everyday narratives act as more detailed representatives of the research material. In this setting, rain and puddles were the weekly themes actualised, for instance, through play, handcrafts, and songs. Both these moments took place during the joint circle time, which served as a forum for common meetings at the beginning and end of the day.

\section{Puddle Play}

It is morning circle time. The children, two teachers and an assistant play 'a puddle game' under the guidance of the teacher, Anna. She spreads a blue cloth in the middle of the circle and says that it is a puddle. Everyone will get a turn in the puddle. Five-year-old Nooa wants to go first and steps into the puddle.

Anna: 'You may jump into the puddle and stand or sit there'.

Nooa sits down. The teacher Miia laughs: 'One sits in a puddle'.

Teachers and some children, including Nooa, laugh.

Anna laughs and tenderly rubs Nooa's feet: 'Fortunately, you have those rain trousers and rubber boots on you'. Nooa smiles at Anna.

The children and adults sing a rain-themed song while clapping their hands on the floor. The song ends with the words 'shiver like a chicken', and at the same time the words are sung, Anna gently shakes Nooa's shoulders. Both Anna and Nooa smile.

On the children's turns, Anna asks if they want to go into the puddle. Some of the two-year-old children refuse, and the two teachers offer alternatives such as you can 'take your bunny with you'.

Maija goes with her bunny, and everyone laughs when at the end of the song, Anna says, 'Quickly out of the puddle, or you'll freeze'. The teachers also let the children refuse to step into the puddle, which many of the youngest ones do.

Anna gently shakes the shoulders of every child at the end of the song. The children smile, and some laugh. Now it is five-year-old Sofia's turn. She crawls into the puddle.

Anna, with an intense, excited voice, looking at the children in the circle, says, 'For Sofia, let's make a pouring rain'. Anna raises her hands high, and Sofia says, 'Eeeh, I think I don't want to go', and tries to withdraw out of the puddle. Anna catches Sofia in an embrace and says laughing, 'Let's make a little rain. You don't have to go into the pouring rain, so you won't quite become totally wet'.

Anna whispers, 'The rain can be quite small, and we can whisper. The rain will only come on the tip of your nose'.

Sofia still does not want to go.

Anna: 'Ordinary rains for everybody, and no one needs to think of becoming totally wet'. She says to Sofia, 'You can think for a while if you want to go there later'. 
Some other children go to the puddle, and the play continues. Anna again asks

Sofia if she wants to go into the puddle. She refuses.

Anna asks Sofia whether Anna can go into the puddle. The children shout: 'YES!'

Anna bounds happily into the puddle and screams, 'Yippee!', and the children laugh at her exaggerated gestures at the end of the song.

During this moment, Anna did not treat the children as a homogenous group (see Fugelsnes 2018). She observed every child's reactions and moods and regulated the force of her joyful gestures depending on their reactions. When Anna noticed that not all the children wanted to cheer out loud, she became more sensitive with them, softening their experiences. In our interpretation, Anna was open and sensitive during this moment. She reached out to each child's perspective, which entailed recognising and acknowledging their otherness. Noticeably, the objective the teachers set for this joint puddle play was that every child had a chance to participate. Anna, along with other teachers, took a dialogic stance, met every child in their uniqueness, allowed them to influence her (see Friedman 2002) and gave up her preconceived objectives. Anna encouraged the children but left them the choice to not participate.

This moment demonstrated Anna's willingness to create an emotionally safe atmosphere. This world full of surprises and unpredictability can seem chaotic (see Buber 1923/1987), especially to young children. A sense of security is an essential prerequisite for dialogue, and adults are the primary filters of the world and its events (Buber 1947/2002) and provider of safety for children. During this moment, Anna often made powerful, joyful gestures, such as laughing cheerfully, as if trying to use exaggeration to convince the children that 'this was not so serious', and there was no correct way to accomplish the task. This playful orientation opened up room for dialogue. In a final attempt to create a safe atmosphere, she jumped into the puddle herself, mediating openness and exposing herself to the moment (see Buber 1923/1987, 1947/2002).

\section{Rain Instruments}

The whole group gathers for afternoon circle time. The teacher, Anna, tells the children that they are about to play with self-made instruments (rhythm sticks made by rolling up newspapers). The instruments are handed out to the children by Anna and the assistant Miika. Five-year-old Matti reaches out with his hand the whole time, first with his right hand and finally using both hands. He watches how Anna and Miika give the instruments to other children. Another boy, Samuli, also five years old, gets one instrument from Miika. While Miika attempts to give another instrument (an extra one from the basket) to Samuli, Anna says, 'Samuli didn't make the other instrument, so he's not going to get one'. Miika puts the instrument back in the basket. When the group begins to play with the instruments, Matti tries to say something to Anna, who tells him, 'You didn't want to make your instruments, so you can't play'.

Samuli begins to sulk. Matti sits silent and still. The rest of the group, under the guidance of Anna, plays with their self-made instruments. The atmos- 
phere is cheerful. While singing a familiar song and getting to its climax, the children express themselves strongly with joyful gestures.

To understand this moment, we have to go backwards in that day. The children was asked to make their own instruments under the guidance of teacher Anna. Although Anna showed how to make two rain sticks, Samuli refused to make one, and Matti made only one stick. Anna reminded many times that both Samuli and Miika are going to need the instruments later that afternoon, 'Hey, Samuli, look. Can you play with only one stick?' Anna showed how the sticks worked and reminded Samuli that he would need the instrument later that afternoon. Samuli said peevishly: 'I don't want to do any more'.

What happens if you do not have the tools to participate in the joint moment? In this case, sulking, Samuli and Matti sat to the side while the other group members played with their instruments. This narrative underlines that the joy and the shared experiences were not always automatic but occasionally made requirements on the children. From the boys' perspective, they certainly felt excluded in this moment. Anna rejected Matti's call and left him to his own devices.

This moment opens up an interesting perspective on the procedural nature of everyday life in ECE. Awareness of earlier events broadens the scene for interpretation. Anna might have anticipated this moment from Miika's viewpoint earlier that day when reminding him about the upcoming situation when he would need the instrument. She supported the boys beforehand but turned her back at the difficult moment. This moment thus shows the special, complex role of dialogue in educational relationships.

Anna obviously had a long-term goal and felt responsibility to teach the boys that they should complete tasks, or they might face unpleasant consequences. This situation can be considered to be a safe place for children to practice cause-effect relationships and a sense of responsibility. Buber (1947/2002) considered conflicts, as long as they occur in a healthy atmosphere, to be valuable in education. However, during these encounters, the teacher's knowledge and authority should not have precedence over approaching the child with the whole heart. According to Buber (1923/1987, 1947/2002), a dialogic encounter demands an attitude of sincerity with no set objectives or foreknowledge. Exuberant joy during the play of the rain instruments underlines the experience of staying outside, and in the moment, cheerfulness is consciously used to emphasise the education objectives.

However, in an education context, it is not only the ongoing moment and its joylessness that is in question. The teachers' professional and ethical responsibilities influence single encounters. As the children's primary filter of the world (Buber 1947/2002), teachers mediate existing knowledge through monologic transmissions (de Vocht 2015). It, therefore, can be argued that in educational relationships, the teachers seek dialogue with the past, present and future realities of the child's life. The general knowledge of childhood and learning required in the teaching profession still endangers the genuine will to reach the other's perspective in everyday situations, which leads to treating individual children as the generalised other. 


\section{Discussion}

Everyday narratives offer multiple life-filled insights into the shared moments of joy among teachers and children in ECE settings. The study contributes to both ECE research and pedagogical practice through its focus on joy, which is often either ignored or taken for granted in education research and practice. Based on the findings, the study presents three main scientific and pedagogical implications.

First, the study uncovers an overall, positive, joyful atmosphere in daily life in the participating ECE centre. Joy was almost constantly present in the joint moments between the teachers and children. This finding accords with education research highlighting the significance of joy for children's learning and overall well-being (Hinton et al. 2008). The education field seems to present a consensus that one objective of education is to produce happy citizens (Cohen 2006). As Lanas (2019) claimed, performing happy childhood can be seen as a requirement for proper students. This might lead to situations where children and adults are expected to enact only positive emotions and hide the negative ones. However, if a positive, joyful atmosphere becomes an imperative in education that raises a question: Does institutional education allow room for expressing and learning from negative emotions, such as sorrow and anger?

Second, the study calls for theoretically reflecting on the relationship between shared joy and dialogue. Is there a direct line between them: Where there is shared joy is there is always a dialogue? In the light of the Buberian dialogue, the relationships between shared joy and dialogue are complicated, and even single moments of shared joy provide opportunities for both I-It and I-Thou relationships. On one hand, joy and dialogue seem to have a reciprocal relationship: encounters arouse joy, and joyful moments open room for dialogue. On the other hand, the asymmetry in educational relationships may lead to events in which adult-child relationships resemble 'I-It' relationships more than 'I-Thou' relationships. For instance, joy can be instrumentalised in teachers' pedagogical purposes, such as allowing children to join in rejoicing as a reward for completed tasks.

Finally, the study provides challenges to reflect on the significance of joy in pedagogical practises. Our results show the potential of moments of shared joy to promote equality and respect in teacher-child relationships. During the joyful moments, customary, institutionally based roles often break. The dialogue of joy occurs when the teachers temporarily give up their traditional role and surrender to unpredictable and jointly constructed joy, and the children can experience confidence and gain agency. The dialogue of joy strengthens the children's experience of being appreciated and encourages active participation and agency. Joyful encounters appear as surprising, open-ended moments bursting out, requiring a dialogical stance and leading to final outcomes impossible to predict. In daily pedagogical practices, dialogical 'I-Thou' encounters do not occur due to purposeful planning and seeking (see Buber 1923/1987). Instead, they require that the teachers value daily, burstingforth moments as spaces to create reciprocal, respectful relationships with children. 
Acknowledgements Open access funding provided by University of Oulu including Oulu University Hospital.

Open Access This article is distributed under the terms of the Creative Commons Attribution 4.0 International License (http://creativecommons.org/licenses/by/4.0/), which permits unrestricted use, distribution, and reproduction in any medium, provided you give appropriate credit to the original author(s) and the source, provide a link to the Creative Commons license, and indicate if changes were made.

\section{References}

Bartholo, R., Tunes, E. M., \& Tacca, M. C. V. R. (2010). Vygotsky's and Buber's pedagogical perspectives: Some affinities. Educational Philosophy and Theory, 42(8), 867-880.

Bellocchi, A., Ritchie, S. M., Tobin, K., King, D., Sandhu, M., \& Henderson, S. (2014). Emotional climate and high quality learning experiences in science teacher education. Journal of Research in Science Teaching, 51(10), 1301-1325. https://doi.org/10.1002/tea.21170.

Bruner, J. (1986). Actual minds, possible worlds. Cambridge: Harvard University Press.

Buber, M. (1923/1987). I and thou. Edinburgh: T. \& T. Clark.

Buber, M. (1947/2002). Between man and man. London: Routledge.

Caine, V., Estefan, A., \& Clandinin, D. J. (2013). A return to methodological commitment: Reflections on narrative inquiry. Scandinavian Journal of Educational Research, 57(6), 1-3. https:// doi.org/10.1080/00313831.2013.798833.

Cekaite, A., \& Andrén, M. (2019). Children's laughter and emotion sharing with peers and adults in preschool. Frontiers in Psychology, 10, 852. https://doi.org/10.3389/fpsyg.2019.00852.

Clandinin, D. J., Cave, M. T., \& Berendonk, C. (2017). Narrative inquiry: A relational research methodology for medical education. Medical Education, 51(1), 89-96. https://doi.org/10.1111/ medu.13136.

Cohen, J. (2006). Social, emotional, ethical, and academic education: Creating a climate for learning, participation in democracy, and well-being. Harvard Educational Review, 76(2), 201-237. https://doi. org/10.17763/haer.76.2.j44854x1524644vn.

De Rivera, J., Possell, L., Verette, J. A., \& Weiner, N. (1989). Distinguishing elation, gladness, and joy. Journal of Personality and Social Psychology, 57(6), 1015-1023. https://doi. org/10.1037/0022-3514.57.6.1015.

De Vocht, L. (2015). Reconceptualising teacher-child dialogue in early years education as a moral answerability. International Journal of Early Childhood, 47(2), 317-330. https://doi.org/10.1007/ s13158-015-0140-2.

Emilson, A., \& Johansson, E. (2009). The desirable toddler in preschool: Communicated values in teacher and child interactions. In D. Berthelsen, J. Brownlee, \& E. Johansson (Eds.), Participatory learning and the early years. Research and pedagogy (pp. 61-77). New York: Routledge. https:// doi.org/10.4324/9780203883556.

Finnish National Core Curriculum for Early Childhood Education and Care. (2016). Helsinki: Finnish National Agency of Education.

Fredrickson, B. (2003). The value of positive emotions. American Scientist, 91(4), 330-335. https://doi. org/10.1511/2003.4.330.

Friedman, M. (2002). Introduction by Maurice Friedman. In M. Buber (Ed.), Between man and man (p. $\mathrm{xi}-\mathrm{xx})$. London: Routledge.

Fugelsnes, K. (2018). Reciprocal caring in ECEC settings. In E. Johansson, A. Emilson, \& A.-M. Puroila (Eds.), Values education in early childhood settings: Concepts, approaches and practices (pp. 187198). Dordrecht: Springer.

Goldman, R., Pea, R., Barron, B., \& Derry, S. J. (2007). Preface. In R. Goldman, R. Pea, B. Barron, \& S. J. Derry (Eds.), Video research in the learning sciences (p. ix-xiii). New York: Routledge.

Gordon, R. (2001). Joy: A Buberian perspective. Shofar: An Interdisciplinary Journal of Jewish Studies, 19(2), 105-116. https://doi.org/10.1353/sho.2001.0173.

Hinton, C., Miyamoto, K., \& Della-Chiesa, B. (2008). Brain research, learning and emotions: Implications for education research, policy and practice. European Journal of Education, 43(1), 87-103. https://doi.org/10.1111/j.1465-3435.2007.00336.x. 
Huhtamäki, E., Holma, H., Nokelainen, P., \& Kumpulainen, K. (2017). Otos iloa-Lasten näkökulmia iloa tuottavista peruskoulun oppimisympäristöistä. [Picture of joy-Childrens' experiences of joyful elementary school learning environments]. Kasvatus: Suomen kasvatustieteellinen aikakauskirja, 48(4), 336-352.

Hyvärinen, M. (2008). Narrative form and narrative content. In I. Järventie \& M. Lähde (Eds.), Methodological challenges in childhood and family research (pp. 43-63). Tampere: Tampere University Press.

Hyvärinen, M., Hydén, L.-C., Saarenheimo, M., \& Tamboukou, M. (2010). Beyond narrative coherence. An introduction. In M. Hyvärinen, L.-C. Hydén, M. Saarenheimo, \& M. Tamboukou (Eds.), Beyond narrative coherence (pp. 1-5). Amsterdam: John Benjamin.

Juutinen, J., \& Viljamaa, E. (2016). A narrative inquiry about values in a Finnish preschool: The case of traffic lights. International Journal of Early Childhood, 48(2), 193-207. https://doi.org/10.1007/ s13158-016-0165-1.

Karjalainen, S., \& Puroila, A-M. (2017). Ilon koodi: Dialogisesti ja kulttuurisesti rakentuvat lasten ilon hetket päiväkodissa. [The code of joy: Children's dialogically and culturally shaped moments of joy in the daily lives of day care centres]. Kasvatus \& Aika, 11(3), 23-36. Retrieved from https://journ al.fi/kasvatusjaaika/article/view/6872.

Kinnunen, S. (2015). How are you? The narrative in-between spaces in young children's daily lives. Oulu: University of Oulu. Retrieved from http://urn.fi/urn:isbn:9789526210285.

Kuby, C. R. (2014). Understanding emotions as situated, embodied, and fissured: Thinking with theory to create an analytical tool. International Journal of Qualitative Studies in Education, 27(10), 12851311. https://doi.org/10.1080/09518398.2013.834390.

Kurki, K. (2017). Young children's emotion and behaviour regulation in socio-emotionally challenging situations. Oulu: University of Oulu. Retrieved from http://urn.fi/urn:isbn:9789526216973.

Lanas, M. (2019). Can performing happy childhood be an occupational skill required of students? Childhood, 26(2), 250-262. https://doi.org/10.1177/0907568218823882.

Lannaman, J. W., \& McNamee, S. (2011). Narratives of the interactive moment. Narrative Inquiry, 21(2), 382-390. https://doi.org/10.1075/ni.21.2.18lan.

Lieblich, A. (2014). About Amos: Reading with our heart. Narrative Works, 4(1), 96-106.

Niemi, R. (2013). Narratiivinen opetusmenetelmä alkuopetuksessa. [Narrative method in primary education]. In E. Ropo \& M. Huttunen (Eds.), Puheenvuoroja narratiivisuudesta opetuksessa ja oppimisessa (pp. 65-84). Tampere: Tampere University Press.

Pink, S. (2009). Doing sensory ethnography. Thousand Oaks: Sage.

Puroila, A.-M. (2013). Young children on the stages: Small stories performed in day care centers. Narrative Inquiry, 23(2), 323-343. https://doi.org/10.1075/ni.23.2.06pu.

Riessman, C. K. (2008). Narrative methods for the human sciences. Los Angeles: Sage.

Segal, L. (2018). Radical happiness: Moments of collective joy. London: Verso.

Singer, E. (2013). Play and playfulness, basic features of early childhood education. European Early Childhood Education Research Journal, 21(2), 172-184. https://doi.org/10.1080/13502 93X.2013.789198.

Spector-Mersel, G. (2010). Narrative research. Time for a paradigm. Narrative Inquiry, 20(1), 204-224.

Tallant, L. (2015). Framing young children's humour and practitioner responses to it using a Bakhtinian carnivalesque lens. International Journal of Early Childhood, 47(2), 251-266.

Turner, E. (2012). Communitas: The anthropology of collective joy. New York: Palgrave Macmillan.

Turner, J. H., \& Stets, J. E. (2014). Handbook of the sociology of emotions. Dordrecht: Springer.

Tuval-Mashiach, R. (2014). Life stories in context: Using the three-sphere context model to analyze Amos's narrative. Narrative Works, 4(1), 125-145.

Vehkalahti, K. (2012). Lapsuuden historiaa tunteella [Childhood, youth and emotions in modern history]. Kasvatus \& Aika, 6(4), 62-65. Retrieved from http://www.kasvatus-ja-aika.fi/ site/?lan=1\&page_id=518.

Viljamaa, E. (2012). Lasten tiedon äärellä: Äidin ja lasten kerronnallisia kohtaamisia kotona. [With children's knowledge: Narrative encounters of a mother and children at home]. Oulu: University of Oulu.

Publisher's Note Springer Nature remains neutral with regard to jurisdictional claims in published maps and institutional affiliations. 